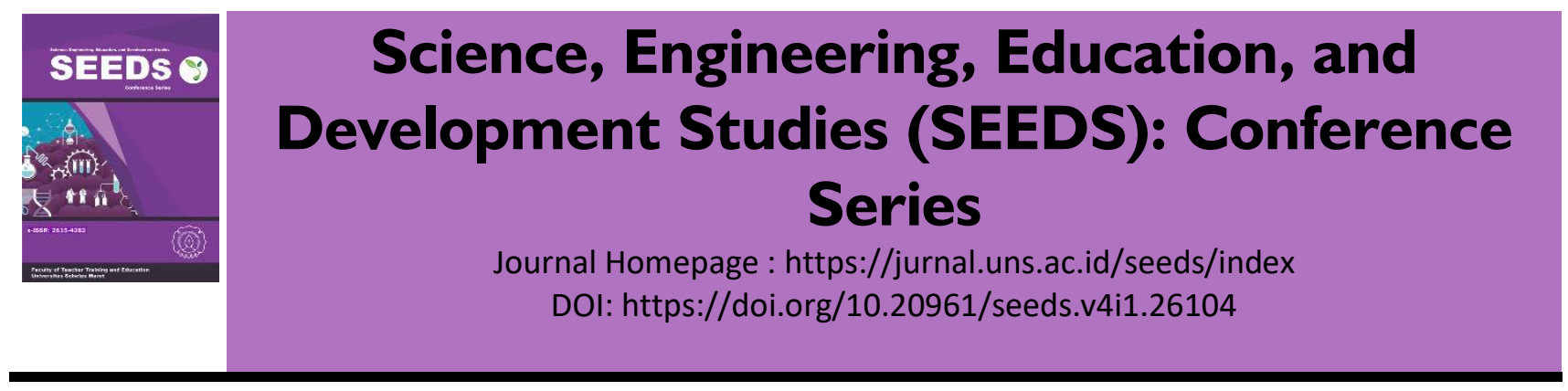

\title{
EFFECTIVENESS OF GOVERNMENT GOODS AND SERVICES PROCUREMENT SYSTEMS (CASE STUDY IN SEBELAS MARET UNIVERSITY)
}

Jaryanto $^{1}$, Wahyudi Sutopo ${ }^{2}$, Salman Alfarisv Totalia ${ }^{3}$

jaryanto_uns@yahoo.com

Article Info :

Available online $24 / 11 / 2021$

Keywords:

Effectiveness

Procurement of goods and services

Assets

\begin{abstract}
This study aims to determine the effectiveness of the procurement of goods and services at Sebelas Maret University. To find out the effectiveness of the system of procurement of goods and services seen from their suitability with the principle of procurement of goods I services and the Standard Operating Procedure (SOP) specified. The principles of procurement of government goods / services include: 1) efficient, 2) effective, 3) transparent, 4) open, 5) competing, 6) fair, and 7) accountable. This study uses a quantitative descriptive approach. The types of data in this study are information or information, both oral, written and actions related to the research variables. The main data from this study are in the form of written questionnaires and field documentation. The population in this study were officers in the procurement of goods and services. The research sample was 30 people and the sampling technique was purposive sampling. The results of the study indicate that the stages of the procurement process of goods and services have been effectively implemented. This is indicated by the process of auction announcements with a score of $87 \%, 88 \%$ auction registration, $88 \%$ job description, $89 \%$ income and bid opening, $90 \%$ bid and qualification evaluation, and 90\% winner determination and announcement. Overall, the process of procurement of goods and services gets a score of $89 \%$ and is included in very suitable / implemented criteria.
\end{abstract}




\section{INTRODUCTION}

The education budget allocation of $20 \%$ from the APBN has not had a significant impact on improving the quality of education in Indonesia (Ministry of Finance, 2018). This is evident from the Indonesian Program for International Student Assessment (PISA) score which is still below Vietnam. Indonesia and Vietnam are two countries that both allocate $20 \%$ of their state budget to the education sector.

Other problems are related to the impact of the allocation of education funds on increasing Indonesia's Gross Domestic Product (GDB). Based on data from the Asian Development Bank (2015) that in 2012 spending on investment in education only had an impact of 3.6\% on GDB. In accordance with international standards, the minimum contribution rate of investment spending in education towards GDB is six percent.

Some of these problems indicate a lack of optimal utilization of education funds in Indonesia, including at the level of higher education. One of the optimal indicators of allocating education funds in higher education to improve the quality of education and GDB can be seen from the effectiveness of the management of goods and services (Azwar, 2016; Alfirman \& Sutriono, 2006; and Manalu, 2004). Procurement of goods and services is goods procurement / services by the Ministry / Institution / Regional Apparatus financed by the APBN / APBD whose process has been since the identification of needs, up to the handover of work results (Presidential Regulation Number 16 of 2018).

This research was conducted to measure the effectiveness of the government procurement of goods and services and the allocation of investment towards the increase in fixed assets of Sebelas Maret University (UNS), especially in the procurement system in 2013 - 2017. The effectiveness of the system of procurement of goods and services is seen from its compatibility with the principles of goods / services procurement and the Standard Operating Procedure (SOP) specified. The principle of procurement of government goods / services includes: 1) efficient, 2) effective, 3) transparent, 4) open, 5) competing, 6) fair, and 7) accountable (Presidential Regulation Number 54 of 2010). This study also examines the impact of the procurement of goods / services on increasing the fixed assets of UNS in an effort to achieve a Key Performance Indicator (KPI) according to the 2015-2019 UNS Business Strategic Plan.

The purpose of this study is to obtain empirical evidence about the impact of the procurement of government goods and services (the system of procurement of goods and services of UNS in 2013 - 2017) towards the improvement of UNS fixed assets and in achieving KPIs set out in the UNS 2015-2019 Business Plan.

\section{LITERATURE REVIEW}

The research roadmap that has been prepared is as follows.Since 2016, it has focused on research on managing universities effectively and efficiently, especially in the fields of finance and governance. The thinking framework in this study is as follows:

The effectiveness of the procurement of government goods and services (procurement of goods and services funded in the 2013-2017 UNS) refers to the seven principles stipulated in Presidential Regulation No. 54 of 2010 which includes: 1) efficient, 2) effective, 3) transparent, 4) open, 5) competing, 6) fair, and 7) accountable. The expected output from the effectiveness of the procurement of goods and services at UNS during 2013 - 2017 is the increasing number of UNS fixed assets. Furthermore, the expected impact of the increase in the number of fixed assets is the achievement of Key Performance Indicators (KPIs) set out in the 2015 UNS Business Strategic Plan. The frame of mindset is shown in Figure 3.1 below:

\section{RESEARCH METHODS}

\section{Types of research}

This study uses a quantitative descriptive approach. Quantitative descriptive is a type of research that aims to describe or describe numbers that have been processed according to certain standardization. The data in this study are quantitative data that is processed to be described. Descriptive method is finding facts with the right interpretation. Descriptive research studies the problems in society and certain situations about the relationship of activities.

\section{Types and Data Sources}


The types of data in this study are information or information, both oral, written and actions related to the research variables. The main data from this study are in the form of written questionnaires and field documentation. Meanwhile, supporting data in the form of: policy documentation related to the procurement of government goods and services, various related scientific works, as well as documented statistical data. Primary data is used to collect information about the process of procurement of goods and services which includes: the stage of auction announcement, auction registration, job description, entry and bid opening, evaluation of bids and qualifications and the determination and announcement of winners.

\section{Population and sample}

The population in this study were officers in the procurement of goods and services within the university eleven March. The sample in this study is the procurement of goods and services in all units and faculties in Sebelas Maret University Surakarta, 30 people

\section{Sampling technique}

The sampling technique used in the study was purposive sampling. The sample was chosen based on involvement in the process of procuring goods and services at the UNS.

\section{Data collection technique}

Data collection techniques in this study are as follows:

a. Questionnaire (Questionnaire) Questionnaires (questionnaires) are questions written in writing to obtain data in the form of answers or information from respondents. The instrument of the questionnaire is related to the research variables.

b. Analysis of archives / documents

Analysis of archives / documents carried out on secondary data in the form of written data / information related to research variables.

\section{Data analysis technique}

Descriptive statistical analysis is used by giving an overview of the data that has been collected so that the data can be easily interpreted according to the category. The analysis was carried out in a descriptive narrative. To measure effectiveness, it is done using descriptive statistical analysis. Descriptive analysis of percentages is used to determine the percentage of each factor based on the respondents' score. To find out the effectiveness of the system of procurement of goods and services seen from their suitability with the principle of procurement of goods / services and the Standard Operating Procedure (SOP) specified. The principles of procurement of government goods / services include: 1) efficient, 2) effective, 3) transparent, 4) open, 5) competing, 6) fair, and 7) accountable

To determine the description of the percentage obtained, the categories are compiled with the following calculations:

1. Determine the highest percentage $=(7 / 7) \times 100 \%=100 \%$

2. Determine the lowest percentage $=(1 / 7) \times 100 \%=14 \%$

3. Determine the range $=100 \%-14 \%=86 \%$

4. Determine creiteria interval $=86 / 4=21 \%$

Criteria for percentage description.

Table 1. Criteria for conformity / implementation of the procurement of goods and services

\begin{tabular}{|c|c|}
\hline Interval & Criteria \\
\hline $14 \%<\%<35 \%$ & does not match the implementation \\
\hline $35 \%<\%<56 \%$ & Sufficiently according to the implementation \\
\hline $56 \%<\%<77 \%$ & according to the implementation \\
\hline $77 \%<\%<100 \%$ & Very appropriate for its implementation \\
\hline
\end{tabular}




\section{Data analysis}

This research takes data about the perception of the procurement of goods and services in all faculties and units at Sebelas Maret University. The data distribution in this study is as follows:

Table 2. Distribution of respondents

\begin{tabular}{lll}
\hline No. & \multicolumn{1}{c}{ Unit Kerja } & Jumlah \\
\hline 1. & University BMN & 8 \\
\hline 2. & Faculty of Engineering & 2 \\
\hline 3. & Faculty of Culture & 2 \\
\hline 4. & Faculty of Law & 2 \\
\hline 5. & Faculty of Social and Political Sciences & 2 \\
\hline 6. & Faculty of Economics \& Business & 2 \\
\hline 7. & Faculty of Art and Design & 2 \\
\hline 8. & Faculty of Teacher Trainning and Education & 2 \\
\hline 9. & Faculty of Medicine & 2 \\
\hline 10. & Faculty of Mathematics and Natural Sciences & 2 \\
\hline 11. & Faculty of Agriculture & 2 \\
\hline 12. & Postgraduate & 30 \\
\hline & & Jumlah \\
\hline
\end{tabular}

The data obtained were then analyzed using descriptive statistical analysis. Based on the results of data analysis, the following results are obtained:

\section{a. Stages of Announcement of Auctions}

Table 3. Results of Assessment of Auction Announcement Stages

\begin{tabular}{lcc}
\hline \multicolumn{1}{c}{ Indicator } & Value & Criteria \\
\hline Transparent & $84 \%$ & Very suitable / implemented \\
\hline Accountability & $89 \%$ & Very suitable / implemented \\
\hline Open & $86 \%$ & Very suitable / implemented \\
\hline Competing & $85 \%$ & Very suitable / implemented \\
\hline Fair / Non-discriminatory & $90 \%$ & Very suitable / implemented \\
\hline A total score & $88 \%$ & Very suitable / implemented
\end{tabular}


b. Stages of Auction Registration

Table 4. Result of Assessment of Auction Registration Stages

\begin{tabular}{lcc}
\hline \multicolumn{1}{c}{ Indicator } & Value & Criteria \\
\hline Transparent & $84 \%$ & Very suitable / implemented \\
\hline Accountability & $89 \%$ & Very suitable / implemented \\
\hline Open & $86 \%$ & Very suitable / implemented \\
\hline Competing & $85 \%$ & Very suitable / implemented \\
\hline Fair / Non-discriminatory & $90 \%$ & Very suitable / implemented \\
\hline A total score & $88 \%$ & Very suitable / implemented \\
\hline
\end{tabular}

c. Stages of Job Explanation (Aanwijzing)

Table 5. Results of Assessment of Job Explanation Stages

\begin{tabular}{lcc}
\hline \multicolumn{1}{c}{ Indicator } & Value & Criteria \\
\hline Transparent & $83 \%$ & Very suitable / implemented \\
\hline Accountability & $85 \%$ & Very suitable / implemented \\
\hline Open & $89 \%$ & Very suitable / implemented \\
\hline Competing & $90 \%$ & Very suitable / implemented \\
\hline Fair / Non-discriminatory & $93 \%$ & Very suitable / implemented \\
\hline A total score & $88 \%$ & Very suitable / implemented \\
\hline
\end{tabular}

\section{d. Stages of Entry and Opening of Bid}

Table 6. Results of Assessment of Entry and Opening Stages

\begin{tabular}{lcc}
\hline \multicolumn{1}{c}{ Indicator } & Value & Criteria \\
\hline Transparent & $84 \%$ & Very suitable / implemented \\
\hline Accountability & $86 \%$ & Very suitable / implemented \\
\hline Open & $92 \%$ & Very suitable / implemented \\
\hline Competing & $92 \%$ & Very suitable / implemented \\
\hline Fair / Non-discriminatory & $91 \%$ & Very suitable / implemented \\
\hline A total score & $89 \%$ & Very suitable / implemented \\
\hline
\end{tabular}


e. Stages of Bid and Qualification Evaluation

Table 7. Results of Evaluation of Bid and Qualification Evaluation Stages

\begin{tabular}{lcc}
\hline \multicolumn{1}{c}{ Indicator } & Value & Criteria \\
\hline Transparent & $87 \%$ & Very suitable / implemented \\
\hline Accountability & $88 \%$ & Very suitable / implemented \\
\hline Open & $90 \%$ & Very suitable / implemented \\
\hline Competing & $92 \%$ & Very suitable / implemented \\
\hline Fair / Non-discriminatory & $93 \%$ & Very suitable / implemented \\
\hline A total score & $90 \%$ & Very suitable / implemented \\
\hline
\end{tabular}

\section{f. Stages of Determination and Announcement of Winners}

Table 8. Results of Assessment of Determination Stages and Announcement of Winners

\begin{tabular}{lcc}
\hline \multicolumn{1}{c}{ Indicator } & Value & Criteria \\
\hline Transparent & $90 \%$ & Very suitable / implemented \\
\hline Accountability & $90 \%$ & Very suitable / implemented \\
\hline Open & $89 \%$ & Very suitable / implemented \\
\hline Competing & $91 \%$ & Very suitable / implemented \\
\hline Fair / Non-discriminatory & $91 \%$ & Very suitable / implemented \\
\hline A total score & $90 \%$ & Very suitable / implemented \\
\hline
\end{tabular}

\section{g. Recapitulation of Indicators for the Procurement of Goods and Services}

Table 9. Recapitulation of Assessment of the Procurement Process of Goods and Services

\begin{tabular}{lcc}
\hline \multicolumn{1}{c}{ Indikator } & Nilai & Kriteria \\
\hline Auction Announcement & $87 \%$ & Very suitable / implemented \\
\hline Auction Registration & $88 \%$ & Very suitable / implemented \\
\hline Job Description & $88 \%$ & Very suitable / implemented \\
\hline Bidding and opening of offer & $89 \%$ & Very suitable / implemented \\
\hline $\begin{array}{l}\text { Evaluation of Bid and } \\
\text { Qualification }\end{array}$ & $90 \%$ & Very suitable / implemented \\
\hline $\begin{array}{l}\text { Determination } \\
\text { Announcement }\end{array}$ & $90 \%$ & Very suitable / implemented \\
\hline \multicolumn{1}{c}{ On average } & $89 \%$ & Very suitable / implemented \\
\hline
\end{tabular}

\section{Discussion}

Based on the results of data analysis on the procurement process of goods and services of the work units in Sebelas Maret University, it can be explained that the entire procurement process is very appropriate / in 
accordance with Presidential Regulation 54 of 2010. The highest evaluation is at the bid evaluation and qualification stages and the winner's determination score of $90 \%$. The lowest rating is at the auction announcement stage with a score of $87 \%$. Overall, the score of procurement of goods and services was $89 \%$ and included in the very appropriate / implemented category.

\section{CONCLUSION}

This study aims to determine the effectiveness of the procurement of goods and services at Sebelas Maret University. To find out the effectiveness of the system of procurement of goods and services seen from their suitability with the principle of procurement of goods / services and the Standard Operating Procedure (SOP) specified. The principles of procurement of government goods / services include: 1) efficient, 2) effective, 3) transparent, 4) open, 5) competing, 6) fair, and 7) accountable.

The results of the study indicate that the stages of the procurement process of goods and services have been effectively implemented. This is indicated by the process of auction announcements with a score of $87 \%, 88 \%$ auction registration, $88 \%$ job description, $89 \%$ income and bid opening, $90 \%$ bid and qualification evaluation, and $90 \%$ winner determination and announcement. Overall, the process of procurement of goods and services gets a score of $89 \%$ and is included in very suitable / implemented criteria

\section{REFERENCES}

Alfirman and Sutriono. (2006). Analysis of the Relationship between Government Expenditures and Gross Domestic Product in Indonesia Using the Granger Causality and Vector Autoregression Approaches. Journal of Public Finance Volume 4 Number 1, 2006.

Asian Development Bank. (2015). Summary of Indonesia’s Education Sector Assessment.

Azwar. (2016). The Government's Allocative Role through the Procurement of Goods / Services and Its Impact on the Indonesian Economy. Financial Economic Study Vol. 20 No. 2, 2006.

Creswell, J. W. (2012). Research Design: Qualitative, Quantitative and Mixed Approaches: Third Edition. Translation: Achmad Fawaid. Yogyakarta: Student Library.

Ministry of Finance. (2018). Minister of Finance: Utilization of Education Budgets Not Optimal. https://www.kemenkeu.go.id/publikasi/berita/menkeu-pemanfaat-anggaran-pendidikan-belum-optimal/.

Manalu, Maria Christina. (2004). Analysis of the Effect of Government Expenditures on Indonesian Economic Growth. USU Institutional Repository.

Sugiyono. (2013). Educational Research Methods (Quantitative, Qualitative Approach and R \& D). Bandung: Alfabeta. 